\title{
PEMISAHAN ALASAN PEMBATALAN DAN SYARAT PELAKSANAAN PUTUSAN ARBITRASE
}

\author{
Melyana \\ Mahasiswa Fakultas Hukum Universitas Tarumanagara \\ Jalan Letjen S. Parman Nomor 1, Jakarta Barat 11440, Indonesia \\ tugasmel@yahoo.com
}

\begin{abstract}
The reasons for the cancellation and the terms of implementation of the arbitration award have been regulated respectively in Law Number 30 of 1999 concerning Arbitration and Alternative Dispute Resolution. Where the reason for canceling the arbitration award has been arranged in a limitative manner and cannot be violated in accordance with Article 70 of Law Number 30 Year 1999 concerning Arbitration and Alternative Dispute Resolution. While the requirements for implementing the arbitration award have also been regulated separately in Article 62 Paragraph (2) of Law Number 30 of 1999 and Circular of the Supreme Court Number 4 of 2016. The research method used is the normative research method. It can be concluded that the reasons for cancellation and the terms of implementation of the arbitral award cannot be confused. Bearing in mind that public order is not a reason for annulment of an arbitral award, but rather a condition that an arbitration award cannot be carried out. Therefore, the Panel of J udges is not allowed to cancel an arbitration award based on reasons other than what is regulated in Article 70 of Law Number 30 Year 1999 concerning Arbitration and Alternative Dispute Resolution.

Keywords: Separation, cancellation and enforcement, Arbitration Award
\end{abstract}

\begin{abstract}
Abstrak, Alasan pembatalan dan syarat pelaksanaan putusan arbitrase telah diatur masingmasing pada Undang-Undang Nomor 30 Tahun 1999 tentang Arbitrase dan Alternatif Penyelesaian Sengketa. Dimana alasan pembatalan putusan arbitrase telah diatur secara limitatif dan tidak dapat disimpangi sesuai dengan Pasal 70 Undang-Undang Nomor 30 Tahun 1999 tentang Arbitrase dan Alternatif Penyelesaian Sengketa. Sedangkan syarat pelaksanaan putusan arbitrase juga telah diatur tersendiri dalam Pasal 62 Ayat (2) Undang-Undang Nomor 30 Tahun 1999 dan Surat Edaran Mahkamah Agung Nomor 4 Tahun 2016. Metode Penelitian yang digunakan adalah metode penelitian normatif. Dapat disimpulkan bahwa alasan pembatalan dan syarat pelaksanaan putusan arbitrase tidak dapat dicampuradukkan. Mengingat bahwa ketertiban umum bukan lah merupakan alasan pembatalan putusan arbitrase, melainkan syarat tidak dapat dilaksanakannya putusan arbitrase. Maka dari itu, Majelis Hakim tidak dibenarkan untuk membatalkan suatu putusan arbitrase berdasarkan alasan-alasan selain dari apa yang diatur di dalam Pasal 70 Undang-Undang Nomor 30 Tahun 1999 tentang Arbitrase dan Alternatif Penyelesaian Sengketa.
\end{abstract}

Kata kunci : Pemisahan, pembatalan dan pelaksanaan, Putusan Arbitrase

\section{Pendahuluan}

Pada dasarnya para pengusaha yang saling melakukan kerja sama melalui perjanjian untuk melakukan transaksi bisnis tidak ingin berhadapan dengan suatu sengketa. Dimana sengketa ini tentu akan membawa sejumlah kerugian dalam bisnisnya. Namun tak dapat dipungkiri, sengketa dapat kapan saja terjadi ketika adanya suatu kepentingan antara para pihak yang saling berbenturan atau berbeda satu sama lain. ${ }^{1}$

${ }^{1}$ Yusna Zaidah, Penyelesaian Sengketa Melalui Peradilan dan Arbitrase Sya'riah Di Indonesia, Cetakan Ke-2, (Yogyakarta: Aswaja Pressindo, 2015), hlm. .3. 
Secara teoretis, untuk menyelesaikan suatu sengketa dikenal dua macam jalur penyelesaian sengketa, yaitu jalur penyelesaian sengketa melalui pengadilan dan di luar pengadilan. Arbitrase merupakan salah satu lembaga penyelesaian sengketa di luar pengadilan yang dikenal di Indonesia. Arbitrase merupakan salah satu dari beberapa alternatif penyelesaian sengketa yang sering kali dipilih oleh para pengusaha. Hal ini mengingat arbitrase memiliki karakteristik yang khusus, seperti arbiter dapat dipilih sendiri oleh para pihak dan telah memiliki pengetahuan khusus mengenai arbitrase, proses pemeriksaan perkara bersifat tertutup, dan jangka waktu penyelesaian sengketa dilaksanakan secara cepat, sederhana dan biaya murah. ${ }^{2}$

Arbitrase itu sendiri merupakan suatu tindakan hukum di mana ada pihak yang menyerahkan sengketa atau selisih pendapat di antara dua orang (atau lebih) maupun dua kelompok (atau lebih) kepada seorang atau beberapa ahli yang disepakati bersama dengan tujuan memperoleh satu keputusan final dan mengikat. ${ }^{3}$

Arbitrase sebagai salah satu alternatif penyelesaian sengketa bukan hal yang baru di Indonesia. Konsep dan pedoman alternatif penyelesaian sengketa telah dimulai sejak tahun 1970, yang dapat dilihat pada Undang-Undang Nomor 14 Tahun 1970 tentang Ketentuan Pokok Kekuasaan Kehakiman yang telah dicabut dan digantikan oleh UndangUndang Nomor 4 Tahun 2004 tentang Kekuasaan Kehakiman ("UU Kekuasaan Kehakiman"), tepatnya dalam Penjelasan Pasal 3 Undang-Undang ini menyatakan, "Ketentuan ini tidak menutup kemungkinan penyelesaian perkara dilakukan di luar peradilan negara melalui perdamaian atau arbitrase". Selain UU Kekuasaan Kehakiman, UU Arbitrase merupakan acuan penyelesaian sengketa di luar pengadilan. Pada dasarnya, arbitrase mirip dengan Pengadilan karena prosedur acaranya seperti sidang Pengadilan sehingga disebut pula "quasi-judicial" atau "semi-pengadilan". 4

Terdapat beberapa lembaga arbitrase yang dikenal di Indonesia, yaitu Badan Arbitrase Nasional Indonesia ("BANI") dan Badan Arbitrase Muamalat Indonesia ("BAMUI") yang telah diganti menjadi Badan Arbitrase Syariah Nasional Indonesia ("BASYARNAS"). Dalam hal para pihak hendak mengajukan penyelesaian sengketa melalui BANI, perlu diperhatikan bahwa para pihak harus telah mencantumkan kehendak tersebut dalam Perjanjian Arbitrase.

Pasal 1 Angka 3 Undang-Undang Nomor 30 Tahun 1999 tentang Arbitrase dan Alternatif Penyelesaian Sengketa ("UU Arbitrase") merumuskan perjanjian arbitrase sebagai suatu kesepakatan berupa klausula arbitrase yang tercantum dalam suatu perjanjian tertulis yang dibuat para pihak sebelum timbul sengketa, atau suatu perjanjian arbitrase tersendiri yang dibuat oleh para pihak setelah timbul sengketa. Kemudian dalam pasal selanjutnya, yaitu Pasal 3 mengatur bahwa Pengadilan Negeri tidak berwenang untuk mengadili sengketa para pihak yang telah terikat dalam perjanjian arbitrase. Karena para pihak terikat pada Perjanjian Arbitrase, maka untuk itu para pihak terikat pula

\footnotetext{
${ }^{2}$ Iswi Hariyani, dkk., Penyelesaian Sengketa Bisnis: Litigasi, Negosiasi, Konsultasi, Pendapat Mengikat, Mediasi, Konsiliasi, Adjudikasi, Arbitrase, dan Penyelesaian Sengketa Daring, Cetakan Pertama, (Jakarta: Gramedia Pustaka Utama, 2018), hlm.141.

${ }^{3}$ Susanti Adi Nugroho, Penyelesaian Sengketa Arbitrase Dan Penerapan Hukumnya, Edisi Pertama, (Jakarta: PRENADAMEDIA GROUP, 2015).

${ }^{4}$ Iswi Hariyani, $d k k$., Loc. Cit, hlm. 133.
} 
dengan asas Pacta Sunt Servanda. Dimana karena sudah terikat dengan asas Pacta Sunt Servanda, maka para pihak telah sepakat dan setuju apabila terjadi sengketa di kemudian hari, maka para pihak akan sepakat untuk memilih lembaga arbitrase untuk menyelesaikan sengketa antara para pihak.

Berdasarkan ketentuan-ketentuan dan prinsip hukum tersebut jelas lah UU Arbitrase telah memberikan kewenangan absolut kepada arbitrase dalam hal para pihak sengketa terikat dalam perjanjian arbitrase. Walaupun demikian, tidak berarti Pengadilan Negeri sama sekali tidak berwenang terhadap sengketa arbitrase. Dalam hal putusan arbitrase telah dijatuhkan, pihak yang kalah tentu tidak akan puas dengan putusan arbitrase tersebut. Terlebih lagi mengingat bahwa Putusan Arbitrase bersifat final and binding. Sehingga terhadapnya tidak dapat diajukan upaya hukum apapun, baik banding, kasasi, dan peninjauan kembali. Hal ini mengingat arbitrase menganut asas peradilan cepat, sederhana dan biaya ringan.

Namun walaupun putusan arbitrase bersifat final and binding, terhadap putusan arbitrase ini masih dapat dilawan dengan permohonan pembatalan arbitrase. Para pihak dapat mengajukan permohonan pembatalan putusan arbitrase tersebut kepada Pengadilan Negeri. Pada kondisi ini lah kewenangan Pengadilan Negeri terhadap sengketa arbitrase muncul. Kewenangan ini didasarkan pada Pasal 71 UU Arbitrase yang menyatakan "permohonan pembatalan putusan arbitrase harus diajukan secara tertulis dalam waktu paling lama 30 (tiga puluh) hari terhitung sejak hari penyerahan dan pendaftaran putusan arbitrase kepada Panitera Pengadilan Negeri”. Namun, tentunya permohonan pembatalan ini tidak dapat dipersamakan dengan pengajuan upaya hukum banding. Dalam hal pengajuan upaya hukum banding, Majelis Hakim memeriksa dan mengadili kembali perkara tersebut. Sedangkan dalam hal para pihak mengajukan permohonan pembatalan putusan arbitrase, Majelis Hakim tidak memeriksa kembali pokok perkara tersebut, melainkan hanya memeriksa apakah putusan arbitrase tersebut memenuhi alasan-alasan pembatalan yang diatur pada UU Arbitrase. Ketentuan mengenai pembatalan arbitrase diatur dalam Pasal 70-72 UU Arbitrase.

Alasan-alasan pembatalan arbitrase sendiri telah diatur pada Pasal 70 UU Arbitrase, yang menyatakan putusan arbitrase dapat diajukan permohonan pembatalan apabila putusan tersebut diduga mengandung unsur-unsur berikut ini:

a. Surat atau dokumen yang diajukan dalam pemeriksaan, setelah putusan dijatuhkan, diakui palsu atau dinyatakan palsu;

b. Setelah putusan diambil ditemukan dokumen yang bersifat menentukan, yang disembunyikan oleh pihak lawan; atau

c. Putusan diambil dari hasil tipu muslihat yang dilakukan oleh salah satu pihak dalam pemeriksaan sengketa.

Selanjutnya perlu diperhatikan pula bahwa selain mengajukan permohonan pembatalan putusan arbitrase, para pihak juga dapat mengajukan permohonan pelaksanaan putusan arbitrase, yang pada asasnya pelaksanaan tersebut seharusnya dilakukan secara sukarela oleh para pihak. Ketika pihak yang kalah tidak mau melaksanakan putusan arbitrase secara sukarela, maka putusan arbitrase tersebut dapat dilaksanakan berdasarkan perintah Ketua Pengadilan Negeri atas permohonan salah satu pihak yang bersengketa, sebagaimana diatur dalam Pasal 61 UU Arbitrase. Syarat-syarat 
untuk melaksanakan putusan arbitrase itu sendiri juga telah diatur pada Pasal 62 Ayat (2) UU Arbitrase yang menentukan "Ketua Pengadilan Negeri sebagaimana dimaksud dalam ayat (1) sebelum memberikan perintah pelaksanaan, memeriksa terlebih dahulu apakah putusan arbitrase memenuhi ketentuan Pasal 4 dan Pasal 5, serta tidak bertentangan dengan kesusilaan dan ketertiban umum." . Dimana substansi dari Pasal 4 dan 5 UU Arbitrase dapat dirincikan sebagai berikut:

a. Para pihak telah menyetujui bahwa sengketa antara para pihak akan diselesaikan melalui arbitrase, dimana persetujuan ini dimuat dalam dokumen yang telah ditandatangani oleh para pihak; dan

b. Sengketa yang dapat diselesaikan melalui arbitrase hanya sengketa pada bidang perdagangan;

Maka dari itu, para pihak dapat memutuskan, apakah ingin mengajukan permohonan pembatalan atau pelaksanaan putusan arbitrase, yang tentunya merupakan dua hal yang berbeda satu sama lain. Apabila salah satu pihak ingin mengajukan permohonan pembatalan putusan arbitrase, maka harus memenuhi alasan-alasan pembatalan sebagaimana dirumuskan dalam Pasal 70 UU Arbitrase. Sedangkan apabila para pihak hendak mengajukan pelaksanaan putusan arbitrase, maka putusan arbitrase tersebut harus memenuhi ketentuan yang telah diatur oleh Pasal 62 Ayat (2) UU Arbitrase.

Berdasarkan hal ini, UU Arbitrase telah mengatur secara jelas mengenai alasanalasan untuk membatalkan maupun syarat-syarat pelaksanaan putusan arbitrase masingmasing. Dimana kedua permohonan ini merupakan dua permohonan yang tidak dapat dipersamakan, baik dari tujuan pengajuan permohonan maupun alasan pengajuan. Satu pihak memohon pembatalan putusan arbitrase, sedangkan di pihak lawan ingin segera memohon pelaksanaan putusan arbitrase. Dalam hal salah satu pihak mengajukan permohonan pembatalan putusan arbitrase, maka di dalam petitumnya setidak-tidaknya akan meminta Majelis Hakim untuk memutus agar putusan arbitrase tersebut dibatalkan, begitu pula pada permohonan pelaksanaan putusan arbitrase.

Terkait pemisahan alasan-alasan permohonan putusan arbitrase dengan syaratsyarat pelaksanaan putusan arbitrase, isu ini muncul dalam Putusan Pengadilan Negeri Nomor 24/PDT.ARB/2015/PN.JKT.PST, yang merupakan putusan atas permohonan pembatalan putusan arbitrase, dimana dalam putusan ini Para Penggugat mendalilkan bahwa putusan arbitrase a quo melanggar ketertiban umum (salah satu syarat tidak dapat dilaksanakannya putusan arbitrase) dan mengandung unsur tipu muslihat (salah satu syarat untuk membatalkan putusan arbitrase). Terhadap permohonan pembatalan ini, Majelis Hakim mempertimbangkan oleh karena putusan arbitrase tersebut melanggar ketertiban umum, maka putusan tersebut kemudian dibatalkan. Putusan ini menunjukkan adanya ketidaksesuaian putusan yang dijatuhkan oleh Majelis Hakim dengan apa yang telah ditentukan oleh UU Arbitrase terkait alasan pembatalan dengan syarat pelaksanaan putusan arbitrase.

Untuk mengetahui lebih lanjut mengenai pemisahan alasan-alasan pengajuan permohonan pembatalan dan syarat pelaksanaan arbitrase, maka Penulis berpandangan perlu adanya kajian lebih lanjut yang kemudian dituangkan dalam penelitian sesuai judul tersebut di atas. Adapun rumusan masalah yang diangkat oleh Penulis adalah: 
1. Bagaimana pemisahan antara alasan pembatalan dan syarat pelaksanaan berdasarkan UU No. 30 Tahun 1999 tentang Arbitrase dan Alternatif Penyelesaian Sengketa?

2. Bagaimana penerapan alasan pembatalan dan syarat pelaksanaan putusan arbitrase dalam Putusan Pengadilan Negeri Nomor 24/PDT.ARB/2015/PN.JKT.PST?

\section{Metode Penelitian}

Metode Penelitian yang digunakan dalam penulisan ini adalah Metode Penelitian Normatif (Normative Legal Research). Dimana metode Sehingga sumber-sumber data yang digunakan oleh Penulis merupakan data kepustakaan. Dimana jenis-jenis data yang digunakan terbagi atas tiga jenis, yaitu bahan hukum sekunder, bahan hukum primer dan bahan hukum tertier. ${ }^{5}$ Bahan Hukum Sekunder berupa semua publikasi yang relevan dengan judul yang Penulis angkat, baik jurnal hukum dan buku-buku hukum. ${ }^{6}$ Untuk Bahan Hukum Primer berupa Undang-Undang Nomor 30 Tahun 1999 tentang Arbitrase dan Alternatif Penyelesaian Sengketa, Undang-Undang Nomor 4 Tahun 2004 tentang Kekuasaan Kehakiman, Putusan Pengadilan Nomor 24/PDT.ARB/2015/PN.JKT.PST, dan beberapa peraturan perundang-undang lainnya yang relevan. Sedangkan untuk Bahan Hukum Tertier yang penulis gunakan adalah Black's Law Dictionary.

Adapun tujuan penelitian ini adalah untuk mengetahui bagaimana penerapan masingmasing alasan pembatalan dan syarat pelaksanaan putusan arbitrase terkait permohonan pembatalan putusan arbitrase yang diajukan kepada Pengadilan Negeri. Sedangkan manfaat penelitian ini terbagi atas 2 (dua) yaitu secara teoretis dan secara praktis. Secara teoretis adalah untuk mengembangkan ilmu pengetahuan dalam bidang hukum, khususnya dalam bidang Hukum Perdata Internasional terkait dengan pembatalan dan pelaksanaan putusan arbitrase. Kemudian secara praktis adalah memberi masukan dalam penerapan alasan-alasan pembatalan dan syarat pelaksanaan putusan arbitrase.

\section{Hasil Penelitian dan Pembahasan}

\section{A. Pemisahan Antara Alasan Pembatalan dan Syarat Pelaksanaan Putusan Arbitrase Berdasarkan Undang-Undang Nomor 30 Tahun 1999 tentang Arbitrase dan Alternatif Penyelesaian Sengketa.}

1. Memahami Arbitrase

Kata Arbitrase dikenal juga dengan istilah arbitrage (Bahasa Belanda), arbitration (Bahasa Inggris) dan arbitrare (Bahasa Latin) yang berarti kekuasaan untuk menyelesaikan sesuatu menurut kebijaksanaan atau perdamaian oleh arbiter atau wasit. ${ }^{7}$ Black's Law Dictionary mengartikan

\footnotetext{
5 Zainuddin Ali, Metode Penelitian Hukum, Edisi Ke-1, Cetakan Ke-8, (Jakarta: Sinar Grafika, 2016), hlm. .105-106.

${ }^{6}$ Ibid., hlm. .47.

${ }^{7}$ Iswi Hariyani, Loc. Cit, hlm. .140.
} 
arbitrase sebagai "A dispute-resolution process in which the disputing parties choose one or more neutral third parties to make final and binding decision resolving the disputes." ${ }^{8}$ Kemudian Pasal 1 Angka 1 UndangUndang Nomor 30 Tahun 1999 tentang Arbitrase dan Alternatif Penyelesaian Sengketa ("UU Arbitrase"), merumuskan arbitrase adalah cara penyelesaian suatu sengketa perdata di luar peradilan umum yang didasarkan pada perjanjian arbitrase yang dibuat secara tertulis oleh para pihak yang bersengketa.

Menurut R. Subekti, arbitrase merupakan "penyelesaian suatu perselisihan (perkara) oleh seorang atau beberapa orang wasit (arbiter) yang bersama-sama ditunjuk oleh para pihak yang berperkara dengan tidak diselesaikan lewat pengadilan"9 Sedangkan menurut Abdulkadir Muhammad, arbitrase didefinisikan sebagai: ${ }^{10}$

"Arbitrase adalah badan peradilan swasta di luar lingkungan peradilan umum, yang dikenal khusus dalam dunia perusahaan. Arbitrase adalah peradilan yang dipilih dan ditentukan sendiri secara sukarela oleh pihakpihak pengusaha yang bersengketa. Penyelesaian sengketa di luar pengadilan negara merupakan kehendak bebas pihak-pihak. Kebebasan ini dapat dituangkan dalam perjanjian tertulis yang mereka buat sebelum dan sesudah terjadinya sengketa sesuai dengan asas kebebasan berkontrak dalam hukum perdata"

Berdasarkan pengertian di atas dapat ditarik beberapa unsur dari badan arbitrase, yaitu: 1) penyelesaian sengketa di luar pengadilan; 2) adanya pihak ketiga yang netral; 3) berdasarkan perjanjian arbitrase; 4) putusan bersifat final and binding; dan 5) khusus di bidang perusahaan.

Terdapat beberapa macam arbitrase yang dikenal. Arbitrase terbagi menjadi arbitrase ad hoc dan arbitrase institusional. ${ }^{11}$ Arbitrase ad hoc merupakan lembaga arbitrase yang dibentuk untuk memeriksa suatu sengketa arbitrase tertentu sesuai dengan kebutuhan saat itu. ${ }^{12}$ Yang berarti arbitrase ad hoc ini hanya menangani kasus per kasus dan bubar saat arbitrase ad hoc telah menyelesaikan sengketa tersebut. ${ }^{13}$ Berbeda dengan arbitrase institusional yang sengaja dibentuk untuk memfasilitasi apabila terdapat pihak-pihak yang hendak menyelesaikan sengketa-sengketa di

${ }^{8}$ Henry Campbell Black, Black's Law Dictionary, 10th ed. (New York: West Publishing Co., 2014).

${ }^{9}$ H. Priyatna Abdurrasyid, Arbitrase dan Alternatif Penyelesaian Sengketa: Suatu Pengantar, (Jakarta: Fikahati Aneska, 2002), hlm. .56.

${ }^{10}$ Rachmadi Usman, Pilihan Penyelesaian Sengketa di Luar Pengadilan, (Bandung: Citra Aditya Bakti, 2003), hlm. .108.

${ }^{11}$ Moch. Basarah, Prosedur Alternatif Penyelesaian Sengketa, Arbitrase Tradisional dan Modern (Online), (Bandung: Genta Publishing, 2011), hlm. .15.

${ }^{12}$ Sudiarto, Negosiasi, Mediasi, dan Arbitrase: Penyelesaian Sengketa Alternatif di Indonesia, (Bandung: Pustaka Reka Cipta, 2015), hlm. .79.

${ }^{13}$ Ibid. 
arbitrase, maka pihak-pihak tersebut dapat mengajukan sengketa tersebut kepada arbitrase institusional.Arbitrase jenis ini tetap berdiri selamanya dan tidak bubar ketika sengketa tersebut selesai (permanen). Sehingga kerap juga dikenal dengan "permanent arbitral body". ${ }^{14}$ Sebagai lembaga arbitrase yang permanen, arbitrase institusional memiliki aturan-aturan yang telah mereka tentukan sendiri. ${ }^{15}$

Ruang lingkup sengketa perdagangan atau bisnis yang dapat diselesaikan oleh BANI adalah semua transaksi bisnis termasuk namun tidak terbatas pada bidang-bidang berikut, yaitu: 1) perdagangan komoditi; 2) perbankan; 3) property \& kawasan berikat; 4) perasuransian; 5) manufakturing; 6) penelitian \& pengembangan teknologi; 7) pasar modal; 8) Hak Kekayaan Intelektual \& franchise; 9) arsitektur \& konstruksi; 10) telekomunikasi, komunikasi \& informatika; 11) peternakan \& perikanan; 12) pemanfaatan ruang udara \& angkasa; 13) periklanan; 14) hiburan; 15) penyiaran; 16) perfilman; 17) perkebunan; 18) restoran,catering, cafe \& kulinari; 19) pertambangan \& energy; 20) lingkungan hidup; 21) pengiriman, pengangkutan \& transportasi darat, laut \& udara; 22) elektronika, lisensi perangkat lunak, IT solution, e-commerce; 23) pembiayaan, modal ventura, penjaminan, pergadaian $\&$ jasa keuangan nonbank lainnya. ${ }^{16}$

Ruang lingkup sengketa ini sesuai dengan apa yang ditentukan secara umum oleh Pasal 66 UU Arbitrase dan penjelasannya yang menyatakan bahwa ruang lingkup arbitrase adalah pada bidang perdagangan dimana kegiatan-kegiatannya terbagi atas bidang perniagaan, perbankan, keuangan, penanaman modal, industri dan hak kekayaan intelektual.

2. Sejarah Arbitrase

Jauh sebelum berlakunya UU Arbitrase, keberadaan arbitrase sudah dikenal sejak zaman penjajahan Belanda yang pengaturannya diatur pada Pasal 377 Herziene Indonesisch Reglement (HIR) atau Pasal 705 Rechtsreglement Buitengewesten ( $\mathrm{RBg})^{17}$ yang berbunyi:m“Jika orang Indonesia dan orang Timur Asing menghendaki perselisihan mereka diputuskan oleh juru pisah maka mereka wajib menuruti peraturan pengadilan perkara yang berlaku bagi bangsa Eropa"

Pasal ini menegaskan bahwa pihak-pihak yang bersengketa diperkenankan untuk menyelesaikan perselisihan di antara mereka melalui juru pisah atau arbitrase apabila mereka menghendakinya. Selain HIR dan

\footnotetext{
${ }^{14}$ Ibid., hlm. .77.

${ }^{15}$ Huala Adolf, Dasar-dasar, Prinsip, dan Filosofi Arbitrase, (Bandung: Keni Media, 2016), hlm. .54 sebagaimana dikutip oleh Cut Memi, "Penyelesaian Sengketa Kompetensi Absolut Antara Arbitrase Dan Pengadilan", Jurnal Yudisial 10, No. 2, 2017, hlm. .122.

16 Teuku Sjahnan, "Tentang BANI", BANI Badan Arbitrase Nasional Indonesia, diakses dari http://baniarbitraseindonesia.org/id_bani.php., pada tanggal 2 Agustus 2019.

${ }_{17}$ Cut Memi, "Implementasi Pembatalan Putusan BANI dan Putusan BAPMI Oleh Pengadilan Negeri", Jurnal Yudisial 8, no. 1 (2015), hlm. .109.
} 
$\mathrm{RBg}$, ketentuan arbitrase juga diatur pada Reglemen Acara Perdata (Reglement op de Bergerlijke Rechtsvordering) atau yang biasa dikenal juga dengan istilah $\mathrm{Rv}$. Rv mengklasifikasikan aturan umum arbitrase ke dalam lima bagian pokok yaitu: 1) Persetujuan arbitrase dan pengangkatan arbitrator atau arbiter; 2) Pemeriksaan di muka badan arbitrase; 3) Putusan arbitrase; 4) Upaya-upaya terhadap putusan arbitrase; 5) Berakhirnya acaraacara arbitrase.

Seiring dengan pertumbuhan dan perkembangan, HIR, RBG, dan Rv dirasa tidak lagi memenuhi perkembangan jaman karena belum meliputi halhal yang berkenaan dengan pengakuan dan pelaksanaan putusan arbitrase asing. Yang kemudian untuk memenuhi kebutuhan ini, Indonesia meratifikasi Convention on the Settlement of Investment Disputes Between States and National of Other States ("ICSID") melalui Undang-Undang Nomor 5 Tahun 1968. Perkembangan ini dilanjutkan dengan diratifikasinya Convention on the Recognition and Enforcement of Foreign Arbitral Award (“Konvensi New York 1958”) melalui Keputusan Presiden Nomor 34 Tahun 1981. Hingga pada tahun 1999, Indonesia membentuk Undang-Undang Nomor 30 Tahun 1999 tentang Arbitrase dan Alternatif Penyelesaian Sengketa.

Sebelum memahami lebih lanjut mengenai pembatalan dan pelaksanaan putusan arbitrase, perlu diketahui terlebih dahulu bahwa putusan arbitrase merupakan putusan yang diberikan oleh arbitrase ad hoc maupun lembaga arbitrase atas suatu perbedaan pendapat, perselisihan paham maupun persengketaan mengenai permasalahan yang lahir dari suatu perjanjian arbitrase. ${ }^{18}$ Dimana putusan arbitrase ini dilakukan tentu dalam rangka mencapai kepastian hukum. Kepastian hukum yang dituangkan dalam putusan merupakan hasil yang didasarkan pada fakta-fakta persidangan, dan penerapannya sesuai dengan kasus yang terjadi sehingga putusan dapat bernilai objektif. ${ }^{19}$

3. Pengaturan Pembatalan Putusan Arbitrase Berdasarkan UU Arbitrase

Sebagaimana telah diuraikan, para pihak dapat mengajukan permohonan pembatalan dalam hal telah adanya penjatuhan putusan arbitrase baik oleh arbitrase ad hoc maupun institusi arbitrase. Dalam hal para pihak ingin mengajukan permohonan pembatalan putusan arbitrase kepada Pengadilan Negeri, maka para pihak perlu memperhatikan beberapa hal yang telah diatur dalam Pasal 70-72 UU Arbitrase, yaitu untuk mengajukan permohonan pembatalan putusan arbitrase kepada Ketua Pengadilan Negeri, pengajuan tersebut diajukan secara tertulis dalam waktu paling lama 30 (tiga puluh) hari terhitung sejak hari penyerahan dan pendaftaran putusan arbitrase kepada Panitera Pengadilan Negeri.

\footnotetext{
18 Rini Fitriani, Arbitrase dan Alternatif Penyelesaian Sengketa di Luar Pengadilan, Edisi Pertama, Cetakan Ke-2, (Yogyakarta: Deepublish, 2016)

${ }^{19}$ I. Ketut Sudira, Mediasi Penal Perkara Penelantaran Rumah Tangga, (Yogyakarta: UII Press, 2016)
} 
Kedua, untuk mengajukan permohonan pembatalan putusan arbitrase dapat diajukan apabila putusan arbitrase tersebut diduga mengandung unsurunsur sebagai berikut:

1. Surat atau dokumen yang diajukan dalam pemeriksaan, setelah putusan dijatuhkan, diakui palsu atau dinyatakan palsu;

2. Setelah putusan diambil ditemukan dokumen yang bersifat menentukan, yang disembunyikan oleh pihak lawan; atau

3. Putusan diambil dari hasil tipu muslihat yang dilakukan oleh salah satu pihak dalam pemeriksaan sengketa.

Alasan-alasan pembatalan di atas kemudian memiliki penjelasan lebih lanjut, yaitu terhadap alasan permohonan pembatalan putusan arbitrase tersebut harus dapat dibuktikan dengan putusan pengadilan. Namun perlu diperhatikan bahwa ketentuan dalam penjelasan tersebut telah dinyatakan batal dan tidak mengikat berdasarkan Putusan Mahkamah Konstitusi Nomor 15/PUU/XII/2014 ${ }^{20}$ karena dianggap rancu dan mengandung norma baru. Sehingga dengan adanya Putusan Mahkamah Konstitusi Nomor 15/PUUXII/2014 tersebut, maka untuk membuktikan alasan-alasan pembatalan putusan arbitrase tidak diperlukan lagi putusan pengadilan.

Terkait alasan-alasan pembatalan putusan arbitrase tersebut, perlu diingat bahwa alasan pembataln putusan tersebut bersifat limitatif. Dimana berarti terhadap pembatalan putusan arbitrase hanya dapat didasarkan pada alasan-alasan yang diatur dalam Pasal 70 UU Arbitrase dan tidak dapat disimpangi dengan alasan apapun. Hal ini telah ditentukan dalam Surat Edaran Nomor 7 Tahun 2012 tentang Rumusan Hukum Hasil Rapat Pleno Kamar Mahkamah Agung Sebagai Pedoman Pelaksanaan Tugas Bagi Pengadilan.

Terakhir, terkait upaya hukum yang dapat dilakukan terhadap permohonan pembatalan putusan arbitrase tersebut terdapat beberapa hal yang perlu diingat. Berdasarkan Pasal 72 Ayat (4) UU Arbitrase Jo. Surat Edaran Mahkamah Agung Nomor 4 Tahun 2016 tentang Pemberlakuan Rumusan Hasil Rapat Pleno Kamar Mahkamah Agung Tahun 2016 Sebagai Pedoman Pelaksanaan Tugas Bagi Pengadilan mengatur bahwa dalam hal putusan Pengadilan Negeri menolak permohonan pembatalan putusan

\footnotetext{
20 Pada putusan ini, Pemohon memohon kepada Mahkamah Konstitusi untuk menyatakan Penjelasan Pasal 70 UU Arbitrase bertentangan dengan Undang-Undang Dasar 1945 dan menetapkan Penjelasan Pasal 70 tidak mempunyai kekuatan hukum. Permohonan ini didasarkan pada dalil apabila Penjelasan Pasal 70 UU Arbitrase tetap berlaku, dimana penjelasan ini menetapkan bahwa alasan-alasan pembatalan sebagaimana yang diatur dalam Pasal 70 harus dibuktikan melalui putusan Pengadilan, maka permohonan pembatalan tidak mungkin dapat diajukan mengingat rentang waktu yang ditentukan oleh Pasal 71 UU Arbitrase menetapkan putusan arbitrase yang hendak diajukan pembatalan harus diserahkan dan didaftarkan pada Panitera Pengadilan Negeri dalam jangka waktu 30 hari sejak putusan arbitrase dijatuhkan. Hal ini tidak dimungkinkan karena putusan pengadilan hampir tidak mungkin dapat menghasilkan putusan dalam rentang waktu 30 hari. Atas permohonan ini, Mahkamah Konstitusi menetapkan bahwa Penjelasan Pasal 70 UU Arbitrase batal dan tidak berkekuatan hukum.
} 
arbitrase, maka tidak tersedia upaya hukum apapun baik banding maupun peninjauan kembali. Dalam hal ini, Pengadilan Negeri dapat membatalkan putusan arbitrase, baik sebagian maupun seluruhnya. ${ }^{21}$ Namun berbeda dengan permohonan pembatalan putusan arbitrase yang dikabulkan oleh Pengadilan Negeri, dalam hal ini terbuka upaya hukum banding kepada Mahkamah Agung yang memutus pertama dan terakhir sehingga perlu diperhatikan bahwa peninjauan kembali juga tidak tersedia.

4. Pengaturan Pelaksanaan Putusan Arbitrase

Selain pembatalan putusan arbitrase, para pihak juga dapat mengajukan permohonan pelaksanaan putusan arbitrase. Pelaksanaan di sini berarti permintaan kepada Ketua Pengadilan Negeri agar dikeluarkan perintah eksekusi terhadap putusan yang dijatuhkan oleh Majelis Arbitrase. ${ }^{22}$ Pengajuan permohonan pelaksanaan ini dilakukan dalam hal pihak yang kalah tidak melaksanakan putusan arbitrase secara sukarela. Pelaksanaan demikian dikenal juga dengan istilah eksekusi paksa, dimana pelaksanaan putusan ini dijalankan berdasarkan putusan pengadilan. ${ }^{23}$ Pelaksanaan putusan arbitrase ini diatur pada Bab VI Pasal 59-64 untuk Arbitrase Nasional dan Pasal 65-69 untuk Arbitrase Internasional. Mengingat dikenal dua macam arbitrase, yaitu arbitrase nasional dan arbitrase internasional.

Berdasarkan Pasal 61 UU Arbitrase, regulasi telah memberikan kewenangan pemberian perintah pelaksanaan putusan arbitrase nasional ini kepada Pengadilan Negeri. Pemberian ini berlandaskan pada prinsip bahwa arbitrase bukanlah merupakan peradilan negara, melainkan merupakan peradilan swasta. Apabila kembali merujuk pada salah satu hukum positif di Indonesia, yaitu Pasal 2 UU Kekuasaan Kehakiman telah mengatur bahwa penyelenggaraan kekuasaan kehakiman dilakukan oleh Mahkamah Agung dan badan peradilan yang berada di bawahnya dalam lingkungan Peradilan Umum, lingkungan Peradilan Agama, lingkungan Peradilan Militer, lingkungan Peradilan Tata Usaha Negara, dan oleh Mahkamah Konstitusi.

Kemudian pada ketentuan Pasal 3 Ayat (1) UU Kekuasaan Kehakiman juga menetapkan bahwa semua peradilan di seluruh wilayah Indonesia adalah peradilan negara dan ditetapkan dengan undang-undang. Dimana penjelasan ayat tersebut merumuskan "Ketentuan ini tidak menutup kemungkinan penyelesaian perkara dilakukan di luar peradilan negara melalui perdamaian atau arbitrase". Melalui ketentuan ini maka jelas lah arbitrase merupakan badan peradilan di luar peradilan negara. Kemudian alasan selanjutnya adalah arbitrase tidak memiliki perangkat juru sita khusus berfungsi untuk melaksanakan perintah eksekusi. Perangkat juru sita hanya terhadap pada lingkungan pengadilan.

${ }^{21}$ Mudakir Iskandar Syah, Penyelesaian Sengketa di Luar Pegadilan Via Arbitrase, (Yogyakarta: CALPULIS, 2016), hlm. .62.

${ }^{22}$ Susanti Adi Nugroho, Loc. Cit., hlm. .278.

${ }^{23}$ Grace Henni Tampongangoy, "Arbitrase Merupakan Upaya Hukum Dalam Penyelesaian Sengketa Dagang Internasional", Lex Et Societatis III, no. 1, hlm. .167. 
Berdasarkan Pasal 61 UU Arbitrase, apabila pihak yang kalah tidak melaksanakan putusan arbitrase secara sukarela, maka putusan dilaksanakan berdasarkan perintah dari Ketua Pengadilan Negeri atas permohonan salah satu pihak yang bersengketa. Kewenangan untuk melaksanakan putusan ini berpedoman pada ketentuan kewenangan relatif, dimana kewenangan didasarkan pada tempat putusan dijatuhkan. ${ }^{24}$ Dalam hal putusan arbitrase dijatuhkan pada BANI Depok, maka Pengadilan Negeri yang memiliki kewenangan adalah Pengadilan Negeri Depok.

Lebih lanjut, dalam Pasal 62 Ayat (2) UU Arbitrase mengatur bahwa sebelum Ketua Pengadilan Negeri memberikan perintah pelaksanaan putusan arbitrase, maka perlu dilakukan pemeriksaan terlebih dahulu apakah putusan arbitrase tersebut memenuhi Pasal 4 dan Pasal 5 UU Arbitrase dan apakah putusan arbitrase tersebut bertentangan dengan kesusilaan dan ketertiban umum. Dimana substansi dari Pasal 4 dan 5 UU Arbitrase dapat dirincikan sebagai berikut:

1. Para pihak telah menyetujui bahwa sengketa antara para pihak akan diselesaikan melalui arbitrase, dimana persetujuan ini dimuat dalam dokumen yang telah ditandatangani oleh para pihak; dan

2. Sengketa yang dapat diselesaikan melalui arbitrase hanya sengketa pada bidang perdagangan.

Selain memeriksa hal-hal yang diatur oleh Pasal 62 Ayat (2) UU Arbitrase, Majelis Hakim juga perlu memeriksa batas jangka waktu pendaftaran putusan arbitrase ke Pengadilan Negeri. Ketentuan ini diatur oleh Pasal 59 Ayat (1) UU Arbitrase yang menentukan bahwa "Dalam waktu paling lama 30 hari terhitung sejak tanggal putusan diucapkan, lembar asli atau salinan autentik putusan arbitrase diserahkan dan didaftarkan oleh arbiter atau kuasanya kepada panitera Pengadilan Negeri”. Pada Ayat (4) pasal tersebut menentukan bahwa dengan tidak didaftarkannya putusan arbitrase tersebut, permohonan pelaksanaan putusan tersebut tidak dapat dilaksanakan.Dalam hal Ketua Pengadilan Negeri menolak permohonan pelaksanaan putusan, para pihak tidak terbuka upaya hukum apapun. Ketua Pengadilan Negeri dapat juga menolak permohonan pelaksanaan putusan arbitrase karena beberapa alasan berikut: ${ }^{25}$

1. Arbiter atau Majelis Arbitrase menjatuhkan putusan melebihi batas kewenangan yang diberikan oleh para pihak dalam sengketa;

2. Putusan dijatuhkan oleh Arbiter atau Majelis Arbitrase yang tidak berwenang untuk memeriksa dan memutus sengketa tersebut;

Hal ini jelas berarti Pengadilan Negeri tidak lagi memeriksa pokok sengketa tersebut (mengingat putusan arbitrase merupakan putusan yang bersifat final and binding), melainkan hanya memeriksa syarat-syarat formil putusan arbitrase. Dalam hal syarat-syarat formil tersebut terpenuhi, maka

\footnotetext{
${ }^{24}$ Susanti Adi Nugroho, Loc. Cit., hlm. .298.

${ }^{25}$ Susanti Adi Nugroho, Loc. Cit. hlm. .279.
} 
Ketua Pengadilan akan mengeluarkan perintah eksekusi. Maka itu, telah jelas diketahui kewenangan Pengadilan Negeri hanya terbatas pada mengabulkan atau menolak putusan arbitrase. Perlu diketahui bahwa, Pengadilan Negeri tidak memeriksa pertimbangan dalam putusan arbitrase ketika diajukannya permohonan pelaksanaan eksekusi. ${ }^{26}$

\section{B. Penerapan Alasan Pembatalan dan Syarat Pelaksanaan Putusan} Arbitrase

1. Kasus Posisi dan Proses Persidangan

Setelah mengetahui alasan untuk membatalkan dan syarat pelaksanaan putusan arbitrase, maka tidak dapat disangkal lagi bahwa alasan dalam mengajukan permohonan untuk membatalkan putusan arbitrase berbeda dengan syarat untuk melaksanakan putusan arbitrase. Alasan pembatalan putusan arbitrase yang telah diatur dalam Pasal 70 UU Arbitrase adalah alasan bersifat limitatif dan tidak dapat disimpangi. Begitu pula syarat pelaksanaan putusan arbitrase sebagaimana telah dipaparkan di atas. Isu mengenai pemisahan kedua jenis permohonan ini dapat terlihat pada Putusan Pengadilan Negeri Jakarta Pusat Nomor 24/PDT.ARB/2015/PN.JKT.PST. Berikut Penulis paparkan proses persidangan antara Penggugat dan Tergugat dalam putusan tersebut secara singkat:

Pada awalnya, Para Penggugat mengajukan gugatan Perbuatan Melawan Hukum kepada Tergugat. Selama proses persidangan tersebut telah berada pada tingkat kasasi, Tergugat juga mengajukan penyelesaian sengketa melalui BANI dengan berdasarkan Perjanjian Arbitrase telah dibuat oleh Para Penggugat dengan Tergugat sebelum terjadinya sengketa. Di mana petitum yang diajukan Tergugat juga memuat hal-hal yang telah diputuskan Majelis Hakim pada gugatan perbuatan melawan hukum tersebut. Kemudian, atas perjanjian arbitrase tersebut, BANI lalu menjatuhkan amar putusan yang mengabulkan permohonan Tergugat (menyatakan surat kuasa dari Penggugat kepada Tergugat untuk memberi suara pada rapat umum pemegang saham atas nama Para Penggugat dalam rangka peralihan saham adalah sah, sehingga kepemilikan saham Para Penggugat menjadi milik Tergugat).

Sedangkan gugatan Perbuatan Melawan Hukum yang diajukan oleh Penggugat, telah sampai pada upaya hukum Peninjauan Kembali. Dimana amar putusan gugatan perbuatan melawan hukum tersebut mengabulkan permohonan dari Para Penggugat (menyatakan surat kuasa tersebut tidak sah, dengan ini kepemilikan saham tetap menjadi milik Para Penggugat) . Di sini berarti BANI dan Pengadilan Negeri menjatuhkan putusan yang berbeda dalam menentukan status kepemilikan saham. Kemudian, untuk melawan

${ }^{26}$ Endrik Safudin, Alternatif Penyelesaian Sengketa dan Arbitrase, (Malang: Intrans Publishing, 2018), hlm. .103. 
Putusan BANI tersebut, Para Penggugat (Para Pemohon) mengajukan permohonan pembatalan putusan BANI dengan dalil sebagai berikut:

1. Putusan BANI No. 547/XI/ARB-BANI/2013 bertentangan dengan ketertiban umum dan kepatutan, atas dasar:

a. BANI tidak berwenang untuk memeriksa kembali dan memutus halhal yang telah memperoleh Putusan yang Berkekuatan Hukum Tetap.

b. BANI tidak memiliki kompetensi absolut

2. Putusan BANI No. 547/XI/ARB-BANI/2013 diduga diambil dari Tipu Muslihat yang dilakukan oleh Tergugat (Termohon)

Atas dalil tersebut Para Pemohon memohon Pengadilan Negeri untuk memutus sebagai berikut:

1. Menerima seluruh permohonan para pemohon;

2. Menyatakan batal dan tidak mempunyai kekuatan hukum seluruh Putusan BANI No. 547/XI/ARB-BANI/2013 tanggal 12 Desember 2014;

3. Menghukum para termohon untuk membayar seluruh biaya perkara ini.

Berdasarkan hal-hal yang telah diterangkan oleh Para Pemohon, Majelis Hakim memberikan pertimbangan sebagai berikut:

Menimbang, bahwa berdasarkan bukti PP-33. A dan PP-53b. yaitu surat kuasa tanggal 3 Juni 2003 dari Nyonya Siti Hardiayanti Rukmana/Pemohon I kepada PT. Berkah Karya Bersama/ Termohon II khusus untuk mewakili dan bertindak untuk dan atas nama principal dalam kapasitasnya sebagai a. pemegang 22.048.000 (dua puluh dua juta empat puluh delapan ribu) saham dalam PT. Cipta Televisi Pendidikan Indonesia dan sebagainya;

Menimbang, bahwa berdasarkan bukti PP-57 bahwa surat kuasa tanggal 3 Juni 2003 tersebut telah dicabut pada tanggal 16 Maret 2005, sehingga tidak dapat lagi dijadikan dasar oleh Termohon II untuk mengadakan RUPSLB pada tanggal 18 Maret 2005;

Menimbang, bahwa menurut ahli Dr. Sutanto bahwa surat kuasa mutlak adalah dilarang, karena dalam praktek sering disalahgunakan;

Menimbang, bahwa meskipun surat kuasa tanggal 3 Juni 2003 telah dicabut pada tanggal 16 Maret 2005, namun RUPSLB tanggal 18 Maret 2005 tetap diselenggarakan dengan dihadiri oleh Termohon II sendiri yang mengaku sebagai kuasa dari Para Pemohon, dimana dalam RUPSLB tanggal 18 Maret 2005 itu, Termohon II telah mengeluarkan suara dengan mengambil keputusan yang mengatasnamakan Para Pemohon yang hasilnya dituangkan dalam Akta Nomor 16 dan 17, keduanya tertanggal 18 Maret 2005 dan dibuat di hadapan Bambang Wiweko, S.H., M.H., Notaris di Jakarta.

Menimbang, bahwa berdasarkan bukti PP-3 dan bukti PP-4 yaitu Putusan Kasasi Mahkamah Agung Nomor: 862K/2013 yang dikuatkan oleh Putusan Peninjauan Kembali Mahkamah Agung Nomor: 238PK/2013 bahwa RUPSLB diselenggarakan dengan dihadiri oleh Termohon II sendiri yang 
mengaku sebagai kuasa dari Para Pemohon. Dalam RUPSLB tanggal 18 Maret 2005 itu, Termohon II telah mengeluarkan suara dengan mengambil keputusan yang mengatasnamakan Para Pemohon yang hasilnya dituangkan dalam Akta Nomor 16 dan 17, keduanya tertanggal 18 Maret 2005 dan dibuat di hadapan Bambang Wiweko, S.H., M.H., notaris di Jakarta. Dimana dalam RUPSLB tanggal 18 Maret 2005 memutuskan 2 (dua) hal penting yaitu:

a. Menyetujui penyelesaian transaksi antara Siti Hardiyanti Rukmana (Pemohon I) dengan Termohon II dengan cara Termohon II masuk sebagai pemegang saham di Pemohon VI (PT. CTPI) dengan cara mengkonversi tagihan yang dikuasai oleh Termohon II menjadi $75 \%$ saham dalam Pemohon VI sehingga saham-saham para pemegang saham Pemohon VI (termasuk Para Pemohon) terdilusi menjadi tinggal 25\%. Keputusan ini dituangkan dalam Akta PKR No. 16 tanggal 18 Maret 2005 yang dibuat oleh Notaris Bambang Wiweko (Akta No. 16 tanggal 18 Maret 2005 - Bukti PP-9, yang oleh Termohon II diajukan sebagai bukti P-21 dalam Perkara BANI No. 547/2013).

b. Menyetujui perubahan pengurus Pemohon VI, sebagaimana dituangkan dalam Akta PKR No. 17 tanggal 18 Maret 2005 yang dibuat oleh Notaris Bambang Wiweko.

telah dibatalkan dan dinyatakan tidak sah dan tidak berkekuatan hukum oleh kedua putusan Mahkamah Agung tersebut, sehingga hasil RUPSLB tanggal 18 Maret 2005 yang menyatakan Termohon II berhak atas 75\% saham di PT. Cipta Televisi Pendidikan Indonesia sampai dengan sebelum Pemohon mengalihkan saham tersebut kepada pihak ketiga, yaitu PT. MNC Tbk. adalah tidak sah dan harus dibatalkan;

Menimbang, bahwa disamping itu karena surat kuasa tanggal 3 Juni 2003 telah dicabut pada tanggal 16 Agustus 2005, namun ternyata dalam Putusan BANI Nomor 547/XI/ARB-BANI/2013 tanggal 12 Desember 2014, dalam amar putusan nomor 3 yang berbunyi menyatakan sah dan mengikat surat kuasa tertanggal 3 Juni 2003 dan surat kuasa tertanggal 7 Pebruari 2003, adalah hal yang bertentangan dengan ketertiban hukum, sehingga tidak dapat dibenarkan menurut hukum dan harus dinyatakan batal;

Atas pertimbangan Putusan BANI di atas yang menyatakan surat kuasa tersebut adalah sah telah bertentangan dengan ketertiban umum in casu putusan pengadilan yang telah berkekuatan hukum tetap, selanjutnya Majelis Hakim menjatuhkan amar putusan:

"Dalam Eksepsi:

a. Menolak eksepsi Termoshon I dan Termohon II;

Dalam Pokok Perkara:

a. Mengabulkan permohonan para pemohon untuk sebagian; 
b. Menyatakan batal dan tidak berkekuatan hukum Putusan Badan Arbitrase Nasional Indonesia (BANI) Nomor: 547/XI/ARB-BANI/2013 tanggal 12 Desember 2014 sepanjang yang berbunyi sebagai berikut:

1) Menyatakan sah dan mengikat Investment Agreement tertanggal 23 Agustus 2002 dan Supplemental Agreement tertanggal 7 Februari 2003;

2) Menyatakan sah dan mengikat Surat Kuasa tertanggal 3 Juni 2003 dan Surat Kuasa tertanggal 7 Februari 2003; ....."

2. Analisis Penerapan Alasan Pembatalan dan Syarat Pelaksanaan Putusan Arbitrase dalam Putusan Pengadilan Negeri Nomor 24/PDT.ARB/2015/PN.JKT.PST.

Berdasarkan sengketa yang telah dipaparkan di atas, terlihat bahwa Para Pemohon mengajukan permohonan pembatalan putusan BANI. Dimana dengan alasan Putusan BANI telah bertentangan dengan ketertiban umum dan mengandung tipu muslihat. Yahya Harahap menyampaikan bahwa ketertiban umum memiliki makna luas dan mendua. Dalam praktek telah timbul beberapa penafsiran mengenai ketertiban umum, antara lain: ${ }^{27}$

1. Penafsiran Sempit

Ketertiban umum diartikan hanya terbatas pada ketentuan hukum positif. Dengan demikian, pelanggaran ketertiban umum hanya terbatas pada pelanggaran terhadap peraturan perundang-undangan.

2. Penafsiran Luas

Ketertiban umum bukan saja terbatas pada peraturan perundangundangan, namun meliputi segala nilai dan prinsip hukum yang hidup di masyarakat, termasuk pula nilai kepatutan dan prinsip keadilan umum.

3. Berpedoman pada Bab V Kitab Undang-Undang Hukum Pidana ("KUHP”)

Pasal 154 - Pasal 181 KUHP diatur berbagai bentuk tindak kejahatan terhadap ketertiban umum. Namun pengertian ketertiban umum ini tidak relevan dengan bidang hukum perdagangan.

Ketertiban umum merupakan salah satu alasan tidak dapat dilaksanakannya putusan arbitrase. Hal ini jelas diatur dalam Pasal 62 Ayat (2) UU Arbitrase. Dalam mempertimbangkan apakah putusan arbitrase tersebut dapat atau tidak dilaksanakan, Majelis Hakim berwenang untuk memeriksa syarat-syarat formil putusan arbitrase, misalnya apakah putusan arbitrase tersebut dijatuhkan oleh arbiter yang tidak berwenang atau apakah putusan arbitrase tersebut melanggar ketertiban umum. Perlu diingat bahwa permohonan pelaksanaan putusan arbitrase diajukan ketika salah satu pihak tidak melaksanakan putusan arbitrase tersebut secara sukarela. Mengingat pelaksanaan putusan arbitrase dapat dilakukan secara sukarela maupun

27 "Ulasan Lengkap : Apa Definisi Ketertiban Umum?", Hukumonline.Com/Klinik, diakses dari https://www.hukumonline.com/klinik/detail/ulasan/lt4e3e380e0157a/apa-definisi-ketertibanumum-/ pada tanggal 2 Agustus 2019. 
paksaan (melalui putusan pengadilan). ${ }^{28}$ Apabila para pihak hendak melaksanakan putusan arbitrase tersebut secara sukarela, maka putusan arbitrase tersebut tentu dapat dilaksanakan tanpa perlu adanya eksekusi paksa dari pengadilan. Ketika suatu putusan dinyatakan tidak dapat dilaksanakan, putusan BANI tersebut tetap mengikat para pihak, hanya saja tidak dapat dilaksanakan oleh pengadilan. Ketika putusan tersebut diputus tidak dapat dilaksanakan dan salah satu pihak masih ingin mencari jalan tengah, maka para pihak masih dapat melakukan negosiasi kembali untuk melaksanakan putusan tersebut secara sukarela, tanpa melalui pengadilan. Dengan demikian pelaksanaan putusan arbitrase tersebut bukan tidak mungkin untuk dilaksanakan. Selain itu, putusan arbitrase ini tetap melekat nebis in idem. ${ }^{29}$

Berbeda dengan esensi dari pembatalan putusan arbitrase yang secara langsung membatalkan putusan arbitrase tepat saat Majelis Hakim menjatuhkan putusan untuk membatalkan putusan arbitrase tersebut. Terhadap putusan arbitrase yang dibatalkan oleh pengadilan dan telah berkekuatan hukum tetap, maka putusan arbitrase tersebut tidak lagi mengikat para pihak bersengketa. Pendapat ini sesuai dengan apa yang dikatakan oleh Yahya Harahap, dimana putusan arbitrase yang dibatalkan oleh ad hoc Committee dianggap tidak pernah ada (never existed) dan semua keadaan sengketa kembali pada keadaan semula serta kekuatan mengikat putusan arbitrase tersebut tidak ada lagi. ${ }^{30}$ Maka dari itu, dapat disimpulkan pembatalan dan pelaksanaan putusan arbitrase berbeda satu sama lain. Bahkan hukum positif Indonesia melalui UU Arbitrase telah menentukan alasan dan syarat masing-masing antara pembatalan dan pelaksanaan putusan arbitrase.

Sehingga menurut pendapat Penulis, tidak dapat dibenarkan apabila Majelis Hakim memutus pembatalan putusan arbitrase dengan pertimbangan putusan arbitrase tersebut bertentangan dengan ketertiban umum. Karena sebagaimana telah diketahui, putusan arbitrase yang melanggar ketertiban umum merupakan syarat tidak dapat dilaksanakannya putusan arbitrase melalui pengadilan, bukan lah untuk membatalkan putusan arbitrase tersebut. Kedua konsekuensi hukum ini adalah dua hal yang berbeda. Terlebih lagi, alasan pembatalan arbitrase juga hanya terbatas apa yang telah ditentukan oleh Pasal 70 UU Arbitrase, bersifat limitatif dan tidak dapat disimpangi. Sehingga tidak tepat apabila Majelis Hakim menjatuhkan putusan pembatalan putusan arbitrase atas dasar alasan di luar Pasal 70 UU Arbitrase. Apalagi jika berdasarkan alasan pelaksanaan putusan arbitrase.

\footnotetext{
${ }^{28}$ Endrik Sadudin, Loc. Cit., hlm. .101.

${ }^{29}$ Yahya Harahap, Arbitrase Ditinjau dari Reglement Acara Perdata (Rv), Peraturan Prosedur BANI, International Centre for the Settlement of Investment Disputes (ICSID), UNCITRAL Arbitration Rules, Convention on the Recognition and Enforcement of Foreign Arbitral Award, PERMA No. 1 Tahun 1990, Edisi Ke-2, (Jakarta: Sinar Grafika, 2004), hlm. .332.

${ }^{30}$ Ibid., hlm. .294.
} 


\section{Penutup}

\section{A. Kesimpulan}

Alasan pembatalan dan syarat pelaksanaan putusan arbitrase telah diatur masing-masing secara tersendiri oleh Undang-Undang Nomor 30 Tahun 1999 tentang Arbitrase dan Alternatif Penyelesaian Sengketa. Alasan pembatalan putusan arbitrase diatur pada Pasal 70 UU Arbitrase, sedangkan syarat pelaksanaan putusan arbitrase ditentukan dalam Pasal 59 dan 62 Ayat (2) UU Arbitrase. Dimana konsekuensi hukum atas pembatalan dan pelaksanaan putusan arbitrase berbeda satu sama lain, dimana apabila suatu putusan arbitrase dibatalkan maka putusan arbitrase tersebut tidak lagi mengikat para pihak dan sengketa tersebut kembali pada keadaan semula. Berlainan dengan putusan arbitrase yang dinyatakan tidak dapat dilaksanakan, putusan arbitrase tersebut tetap mengikat para pihak hanya saja tidak dapat dilaksanakan oleh Pengadilan. Sehingga alasan dan syarat dari masing-masing kedua permohonan tersebut tidak dapat dicampuradukkan. Terlebih lagi, Surat Edaran Mahkamah Agung telah menetapkan bahwa alasan-alasan pembatalan putusan arbitrase sebagaimana diatur dalam Pasal 70 UU Arbitrase bersifat limitatif dan tidak dapat disampingi.

\section{B. Saran}

Penulis merekomendasikan agar Para Majelis Hakim yang diamanahkan untuk memeriksa dan mengadili permohonan pembatalan putusan arbitrase dapat menerapkan alasan-alasan pembatalan dan syarat pelaksanaan putusan arbitrase yang telah ditentukan dalam Undang-Undang Nomor 30 Tahun 1999 tentang Arbitrase dan Alternatif Penyelesaian Sengketa, sebagai acuan dalam menjatuhkan putusan terkait pembatalan putusan arbitrase.

\section{Daftar Pustaka}

\section{A. Buku}

Abdurrasyid, H. Priyatna. Arbitrase dan Alternatif Penyelesaian Sengketa: Suatu Pengantar, Fikahati Aneska, Jakarta, 2002.

Adolf, Huala. Dasar-dasar, Prinsip, dan Filosofi Arbitrase. Keni Media, Bandung, 2016).

Ali, Zainuddin. Metode Penelitian Hukum. Edisi Ke-1. Cetakan Ke-8. Sinar Grafika, Jakarta, 2016.

Basarah, Moch, Prosedur Alternatif Penyelesaian Sengketa, Arbitrase Tradisional dan Modern (Online), Genta Publishing, Bandung, 2011.

Fitriani, Rini. Arbitrase dan Alternatif Penyelesaian Sengketa di Luar Pengadilan. Cetakan Kedua. Deepublish, Yogyakarta, 2016.

Harahap, Yahya. Arbitrase Ditinjau dari Reglement Acara Perdata (Rv), Peraturan Prosedur BANI, International Centre for the Settlement of Investment Disputes (ICSID), UNCITRAL Arbitration Rules, Convention on the 
Recognition and Enforcement of Foreign Arbitral Award, PERMA No. 1 Tahun 1990, Edisi Ke-2, Sinar Grafika, Jakarta, 2004.

Hariyani, Iswi, dkk., Penyelesaian Sengketa Bisnis: Litigasi, Negosiasi, Konsultasi, Pendapat Mengikat, Mediasi, Konsiliasi, Adjudikasi, Arbitrase, dan Penyelesaian Sengketa Daring, Cetakan Pertama. Gramedia Pustaka Utama, Jakarta, 2018.

Nugroho, Susanti Adi. Penyelesaian Sengketa Arbitrase Dan Penerapan Hukumnya, Edisi Pertama. Prenadamedia Group, Jakarta, 2015.

Safudin, Endrik. Alternatif Penyelesaian Sengketa dan Arbitrase, Intrans Publishing, Malang, 2018.

Sudiarto, Negosiasi, Mediasi, dan Arbitrase: Penyelesaian Sengketa Alternatif di Indonesia, Pustaka Reka Cipta, Bandung, 2015.

Sudira, I Ketut. Mediasi Penal Perkara Penelantaran Rumah Tangga, UII Press, Yogyakarta, 2016.

Syah, Mudakir Iskandar. Penyelesaian Sengketa di Luar Pengadilan Via Arbitrase. CALPULIS, Yogyakarta, 2016

Usman, Rachmadi. Pilihan Penyelesaian Sengketa di Luar Pengadilan, Citra Aditya Bakti, Bandung, 2003.

Zaidah, Yusna. Penyelesaian Sengketa Melalui Peradilan dan Arbitrase Syari'ah Di Indonesia, Cetakan Ke-2. Aswaja Pressindo, Yogyakarta, 2015.

\section{B. Artikel Jurnal}

Memi, Cut, "Implementasi Pembatalan Putusan BANI Dan Putusan BAPMI Oleh Pengadilan Negeri", Jurnal Yudisial 8, No. 1, 2015.

, "Penyelesaian Sengketa Kompetensi Absolut Antara Arbitrase Dan Pengadilan", Jurnal Yudisial 10, No. 2, 2017.

Tampongangoy, Grace Henni, "Arbitrase Merupakan Upaya Hukum Dalam Penyelesaian Sengketa Dagang Internasional", Lex Et Societatis III No. 1, 2015.

\section{Internet}

BANI, "Ulasan Lengkap : Apa Definisi Ketertiban Umum?", Hukumonline.Com/Klinik, https://www.hukumonline.com/klinik/detail/ulasan/lt4e3e380e0157a/apadefinisi-ketertiban-umum-l, diakses 2 Agustus 2019.

Sjahnan, Teuku. "Tentang BANI", BANI Badan Arbitrase Nasional Indonesia, http://baniarbitraseindonesia.org/id bani.php, diakses 2 Agustus 2019

"Apa Itu Arbitrase", BANI Badan Arbitrase Nasional Indonesia, http://baniarbitraseindonesia.org/id_arbitrase.php?id=1, diakes 2 Agustus 2019. 


\section{Peraturan Perundang-undangan}

Undang-Undang Nomor 4 Tahun 2004 tentang Kekuasaan Kehakiman (Lembaran Negara Republik Indonesia Nomor 8 Tahun 2004, Tambahan Lembaran Negara Republik Indonesia Nomor 4358).

Undang-Undang Nomor 30 Tahun 1999 tentang Arbitrase dan Alternatif Penyelesaian Sengketa (Lembaran Negara Republik Indonesia Nomor 138 Tahun 1999, Tambahan Lembaran Negara Republik Indonesia Nomor 3872).

Surat Edaran Mahkamah Agung Nomor 7 Tahun 2012 tentang Rumusan Hukum Hasil Rapat Pleno Kamar Mahkamah Agung Sebagai Pedoman Pelaksanaan Tugas Bagi Pengadilan.

Surat Edaran Mahkamah Agung Nomor 4 Tahun 2016 tentang Pemberlakuan Rumusan Hasil Rapat Pleno Kamar MA Tahun 2016 Sebagai Pedoman Pelaksanaan Tugas Bagi Pengadilan.

\section{E. Putusan Pengadilan}

Putusan Pengadilan Negeri Jakarta Pusat Nomor 24/PDT.ARB/2015/PN.JKT.PST perihal permohonan pembatalan putusan arbitrase Nomor 547/XI/ARBBANI.2013.

Putusan Mahkamah Konstitusi Nomor 15/PUU-XII/2014. 